\title{
Mechanism of Chloramphenicol and Tetracycline Resistance in Escherichia coli
}

\author{
BY S. OKAMOTO and D. MIZUNO \\ National Institute of Health, and Faculty of Pharmaceutical Sciences, \\ University of Tokyo, Tokyo, Japan
}

(Received 21 October 1963)

\section{SUMMARY}

The protein-synthesizing activity of cell-free preparations of Escherichia coli was estimated by adding radioactive amino acids according to the system of Matthei \& Nirenberg (1961). Cell-free systems were prepared from antibiotic-sensitive strains of $E$. coli and from resistant variants, and the sensitivity of amino acid incorporation to inhibition by chloramphenicol and tetracycline determined. The same sensitivity was shown for the sensitive as for the resistant strains.

\section{INTRODUCTION}

Several explanations have been proposed to account for bacterial resistance to chloramphenicol, for example: increased production of chloramphenicol reductase (Merkel \& Steers, 1953; Miyamura, 1961), changes in permeability (Kuschner, 1955), and alteration of the process of protein synthesis (Ramsey, 1958). However, for none of these explanations is the experimental evidence conclusive. In a preliminary account (Okamoto \& Mizuno, 1962), we reported that a cell-free system for amino acid incorporation into protein prepared from a chloramphenicol-resistant strain of Escherichia coli в was almost as sensitive to chloramphenicol inhibition as was that from the wild type of $\boldsymbol{E}$. coli в. The present paper gives a more detailed description of this work, together with further experimental work. The extended programme included examination of resistance to tetracycline exhibited by this chloramphenicolresistant strain as well as by in vitro-developed tetracycline-resistant strains, and also by another type of chloramphenicol and tetracycline resistance, i.e. the multiple drug resistance transferable by ' $R$ factor' (review by Watanabe, 1963). Results similar to those previously reported were obtained in all these cases.

\section{METHODS}

Strains used. The following five strains were examined: (1) Escherichia coli в, wild strain; (2) a chloramphenicol-resistant strain (в CMR) developed in vitro from E. coli B as described by Okamoto \& Mizuno (1962); (3) E. coli к 12 cs-2 (Skaar \& Garen, 1956); (4) a multiple drug-resistant strain ( $\mathrm{K} \mathrm{mR}$ ) obtained by transfer of resistance into $E$. coli $\mathrm{K} 12 \mathrm{cs-2}$ from a resistant strain of Shigella isolated from a natural source, kindly supplied by $\mathrm{Mr} \mathrm{H}$. Ikeda of our laboratory; (5) tetracyclineresistant strains isolated from $E$. coli $\mathrm{x} 12$ cs 101 (Hfr), (Skaar \& Garen, 1956) by successive passages through liquid media containing increasing concentrations of tetracycline(strains K TCR). This procedure was performed chiefly by Mrs N. Okamoto. 
Twelve independent cultures were used, but only two of them (nos. 3 and 5) attained resistance to tetracycline $100 \mu \mathrm{g} . / \mathrm{ml}$. without losing their $\mathrm{Hfr}$ character. Several independent cultures from each of the two were further developed to higher degrees of resistance, and five strains were obtained which could grow in the presence of more than $300 \mu \mathrm{g}$. tetracycline $/ \mathrm{ml}$. They were designated as TCR $5 \mathrm{~A}$, 5 B, 5-350, 5-900, TCR 3c. Since precise genetic analysis was not performed, it is not known whether these strains were genetically different or not.

Table 1. Sensitivity of the strains of Escherichia coli to various antibiotics

The figures indicate the concentrations $(\mu \mathrm{g} . / \mathrm{ml}$.) of antibiotics which produce $50 \%$ inhibition of growth as determined by the method described by Treffers (1956).

\begin{tabular}{|c|c|c|c|c|c|c|}
\hline \multirow[b]{2}{*}{$\begin{array}{c}\text { Escherichia } \\
\text { coli }\end{array}$} & \multicolumn{6}{|c|}{ Antibiotic } \\
\hline & $\begin{array}{l}\text { Chloram- } \\
\text { phenicol }\end{array}$ & $\begin{array}{l}\text { Tetra- } \\
\text { cycline }\end{array}$ & $\begin{array}{l}\text { Peni- } \\
\text { cillin }\end{array}$ & $\begin{array}{c}\text { Erythro- } \\
\text { mycin }\end{array}$ & $\begin{array}{c}\text { Strepto- } \\
\text { mycin }\end{array}$ & $\begin{array}{c}\text { Poly- } \\
\text { myxin B }\end{array}$ \\
\hline et & \multicolumn{6}{|c|}{ Concentration ( $\mu \mathrm{g} . / \mathrm{ml}$.$) for \mathbf{5 0} \%$ growth inhibition } \\
\hline $\mathbf{B}$ & $0 \cdot 3$ & $1 \cdot \mathbf{3}$ & 7 & 10 & $\mathbf{1}$ & $1 \cdot 2$ \\
\hline B CMR & 300 & 22 & 100 & 170 & $1 \cdot 3$ & $0 \cdot 3$ \\
\hline к 12 & $0 \cdot 6$ & $3 \cdot 6$ & 15 & 22 & 0.75 & $1 \cdot 8$ \\
\hline $\mathbf{K} \mathbf{~ m R}$ & 90 & 25 & 16 & 25 & 10 & $0 \cdot 4$ \\
\hline K TCR 5-900 & 15 & 100 & 130 & 100 & $0 \cdot 25$ & $0 \cdot 25$ \\
\hline
\end{tabular}

The sensitivity of the strains to various antibiotics is shown in Table 1 as the concentration required to inhibit the bacterial growth by $50 \%$. As shown, strain B CMR was about a thousand times as resistant to chloramphenicol as the wild strain and exhibited cross-resistance against tetracycline, penicillin and erythromycin, but was sensitive to streptomycin, as reported earlier by Szybalsky \& Bryson (1952); strain $\mathrm{k} \mathrm{mR}$ was resistant to chloramphenicol, tetracycline and streptomycin, but not to erythromycin and penicillin. Strain $\mathrm{K}$ TCR shows similar patterns of crossresistance to those of strain B CMR. All resistant strains were somewhat more sensitive to polymyxin B than were their wild types.

Culture medium and cultural conditions. The culture medium consisted of the following ingredients : $0 \cdot 1 \mathrm{M}$-solution of $\mathrm{MgSO}_{4}, 10 \mathrm{ml}$.; $0.01 \mathrm{M}$-solution of $\mathrm{KH}_{2} \mathrm{PO}_{4}$, $3.2 \mathrm{ml}$; $20 \%$ (w/v) solution of glucose, $5 \mathrm{ml}$; $\mathrm{NaCl}, 3 \mathrm{~g}$.; Polypepton (Daigo Eiyo Co.), $10 \mathrm{~g} . ;$ in a total volume of $1000 \mathrm{ml}$; ; adjusted to $\mathrm{pH} \mathrm{7 \cdot 2.} \mathrm{An} \mathrm{overnight} \mathrm{shaken}$ culture (incubated at $37^{\circ}$ ) was transferred to about 50 vol. of fresh medium and the culture incubated with aeration. In the case of strains B CMR and $\mathrm{K} \mathrm{mR}$, chloramphenicol was added to the medium at $30 \mu \mathrm{g} . / \mathrm{ml}$. The TCR strains were pre-cultured in the presence of tetracycline $100 \mu \mathrm{g} . / \mathrm{ml}$. and then grown in a large-scale culture (5 l.) in medium containing tetracycline $20 \mu \mathrm{g} . / \mathrm{ml}$.

Preparation of cell-free system. When the culture reached early logarithmic phase, it was chilled rapidly with ice; the organisms were harvested (centrifugation) and washed twice with $0.05 \mathrm{M}$-tris buffer $(\mathrm{pH} \mathrm{7 \cdot 6})$ containing $8 \times 10^{-3} \mathrm{M}-\mathrm{MgCl}_{2}$. In later experiments this buffer, which was also used for the preparatory procedure and dialysis, was modified according to Matthei \& Nirenberg (1961) to include $0.06 \mathrm{M}-\mathrm{KCl}$ and $0.006 \mathrm{M}-\beta$-mercaptoethanol. The washed organisms were suspended in about $2 \mathrm{vol}$. 
of the buffer and disrupted by sonic treatment (Okamoto \& Mizuno, 1962) or, in later experiments, by passage through a French pressure cell. The latter procedure gave more active preparations. The disrupted-cell suspension was centrifuged twice at $30,000 \mathrm{~g}$ for $30 \mathrm{~min}$. to remove whole organisms and large debris, and the final supernatant fluid was kept as ' 3 s fraction'. The 3 s fraction was further fractionated by centrifugation at $100,000 \mathrm{~g}$ for $60 \mathrm{~min}$. to give supernatant fraction (10s) and pellet fraction (ribosome fraction); the ribosome fraction was washed once by resuspending and sedimenting at $100,000 \mathrm{~g}$, and the $10 \mathrm{~s}$ fraction was dialysed overnight against tris buffer ( $\mathrm{pH} 7 \cdot 6$ ) containing $8 \times 10^{-3} \mathrm{M}-\mathrm{MgCl}_{2}$, at $4^{\circ}$. In later experiments the 3 s fraction was directly dialysed against buffer containing $\beta$ mercaptoethanol and kept frozen before use.

Assay of incorporation of ${ }^{14} \mathrm{C}$-amino acids into protein by the cell-free system. The ribosome fraction (equiv. about $2 \mathrm{mg}$. protein) together with the 10s fraction (equiv. about $1 \mathrm{mg}$. protein) were incubated with ${ }^{14} \mathrm{C}$-amino acids and necessary cofactors as described previously. In later experiments dialysed 3s fraction was chiefly employed and the reaction mixture was modified according to Matthei \& Nirenberg (1961), as follows: 3s fraction, equiv. 2-3 mg. protein; tris buffer $(0.05 \mathrm{M}, \mathrm{pH} 7 \cdot 6) ; \mathrm{MgCl}_{2}, 8 \times 10^{-3} \mathrm{M} ; \mathrm{KCl}, 6 \times 10^{-2} \mathrm{M}$; adenosine triphosphate (ATP) Na salt, $1 \mu \mathrm{mole} / \mathrm{ml}$; creatine phosphate, Na salt, $5 \mu \mathrm{moles} / \mathrm{ml}$.; creatine kinase, equiv. $0.1 \mathrm{mg}$. protein $/ \mathrm{ml}$; guanosine triphosphate (GTP), 0.03 $\mu$ mole/ml.; $\beta$-mercaptoethanol $0.006 \mathrm{M} ;{ }^{14} \mathrm{C}$-amino acid mixture (hydrolysed algal protein, specific activity $6.88 \mathrm{mc} / \mathrm{mm}$, supplied by the Institute of Applied Microbiology, University of Tokyo), $2 \times 10^{5}$ c.p.m./tube (counted with the windowless gas-flow counter); antibiotic to be tested at the required concentration; the total volume was 0.3 or $0.5 \mathrm{ml}$. After incubation at $37^{\circ}$ for $45 \mathrm{~min}$., the reaction was stopped by adding about $5 \mathrm{ml}$. of $5 \%$ trichloroacetic acid (TCA). The radioactivity incorporated into the hot-acid insoluble fraction was counted, and the degree of inhibition by the antibiotic assayed as described (Okamoto \& Mizuno, 1962). Counting was performed with a windowless gas-flow counter or with a thin-window gas-flow counter equipped with an automatic sample changer; the counting efficiency of the latter was about one-fourth that of the former. All the data are presented as values to be obtained with the windowless gas-flow counter.

\section{RESULTS}

Inhibition of the amino acid incorporation with chloramphenicol in the cell-free system of Escherichia coli

The inhibition of amino acid incorporation in the cell-free preparations of Escherichia coli B and strain в CMR was examined. The results are shown graphically in Fig. 1. Almost identical inhibition curves were obtained with the wild-type and the chloramphenicol-resistant strains. The same kind of experiment with the cellfree systems of strains $\mathrm{K}$ and $\mathrm{K} \mathrm{mR}$ gave similar inhibition patterns, as shown in Fig. 2. In both cases the amino acid incorporation system of the resistant strain was as sensitive, within the experimental errors, to inhibition by chloramphenicol as that of the sensitive strain.

It should be noted that the amino acid incorporation in these systems was inhibited about $50 \%$ by $2.5 \mu \mathrm{g}$. chloramphenicol $/ \mathrm{ml}$. and about $80 \%$ with $40 \mu \mathrm{g} . / \mathrm{ml}$.; 
the inhibition was not complete even in the presence of $200 \mu \mathrm{g} . / \mathrm{ml}$., where the inhibition was about $80-90 \%$.

\section{Inhibition with tetracycline}

Amino acid incorporation by the cell-free system of the wild strain, Escherichia coli $\mathrm{K} 12$, was inhibited also by tetracycline; the inhibition was about $40-50 \%$ at $40 \mu \mathrm{g} . / \mathrm{ml}$. and about $80 \%$ at $160 \mu \mathrm{g} . / \mathrm{ml}$. Thus the concentration of tetracycline required to inhibit the cell-free system was considerably higher than that required for growth inhibition. However, when growth inhibition with tetracycline was examined in the medium supplemented with $\mathrm{MgCl}_{2}(0.008 \mathrm{M})$ and $\mathrm{KCl}(0.06 \mathrm{M})$, the concentration of tetracycline which caused $50 \%$ inhibition of growth was about

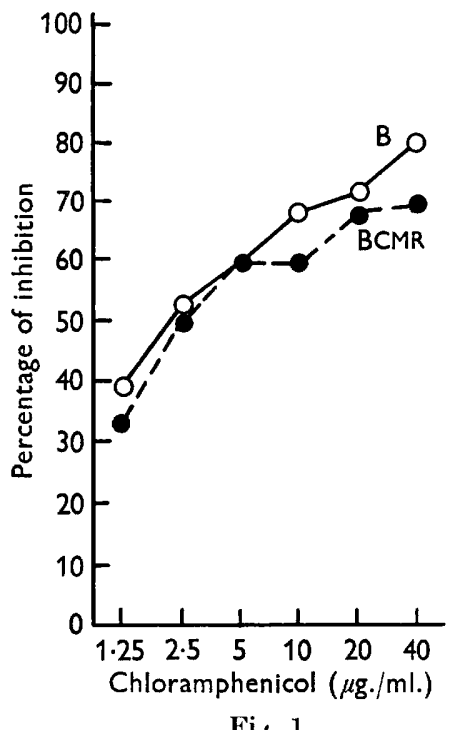

$\mathrm{Fi}_{\mathfrak{a}} \cdot 1$

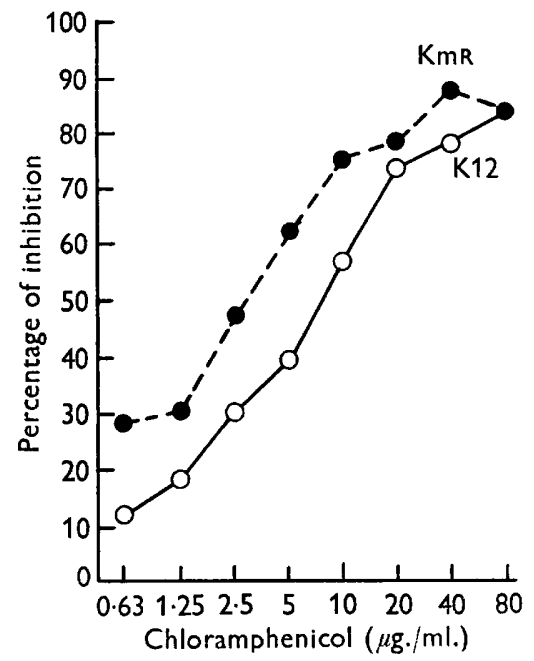

Fig. 2

Fig. 1. Effect of chloramphenicol on amino acid incorporation by cell-free systems of Escherichia coli B and strain B CMR. The reaction mixture contained about equiv. 1-3 mg. protein of ribosomal fraction and about $1 \mathrm{mg}$. protein of $10 \mathrm{~s}$ fraction. Incubation was at $37^{\circ}$ for $20 \cdot \mathrm{min}$; ; other conditions as described in the text. Each point represents the average value of two or three independent experiments. The value for complete system without antibiotic ranged from 120 to 600 counts $/ \mathrm{min} . / \mathrm{mg}$. protein, depending on the experiment. The radioactivity is corrected for the value of the 20-0 time control of 20-80 counts/min./mg. protein, and not corrected for self-absorption.

Fig. 2. Effect of chloramphenicol on amino acid incorporation by cell-free systems of Escherichia coli strains $\mathrm{K}$ and $\mathrm{K} \mathrm{mR}$. Conditions are similar to Fig. 1. Average data of from two to four experiments are shown.

$20 \mu \mathrm{g} . / \mathrm{ml}$. for $E$. coli $\mathrm{k} 12$, about $100 \mu \mathrm{g} . / \mathrm{ml}$. for $\mathrm{K} \mathrm{mR}$, and about $300 \mu \mathrm{g} . / \mathrm{ml}$. for $\mathrm{K}$ TCR strains. Under these circumstances, therefore, the tetracycline concentration which caused $50 \%$ inhibition of growth of $E$. coli $\mathrm{k} 12$ was not very different from that which caused $50 \%$ inhibition of the cell-free system.

As shown in Table 1, strain B CMR exhibited considerable cross-resistance to tetracycline, and strain $\mathrm{K} \mathrm{mR}$ was also resistant to it. The sensitivity to tetracycline of cell-free amino acid incorporation by these resistant strains was identical with that of their wild strains (Figs. 3, 4). 
Since it was reported by Yokota \& Akiba (1962) that a tetracycline-resistant strain of Escherichia coli selected in vitro by using tetracycline gave tetracyclineresistant ribosomes, we examined the sensitivity to tetracycline of cell-free preparations from several in vitro-developed tetracycline-resistant strains of $E$. coli к 12 . Representative results are shown in Table 2. The cell-free systems of the TCR strains investigated were, again, as sensitive to the effect of tetracycline as that of $\boldsymbol{E}$. coli $\mathrm{K}$ wild strain, with some slight differences, especially in the case of TCR $3 \mathrm{c}$. Two other TCR strains tested gave similar results.

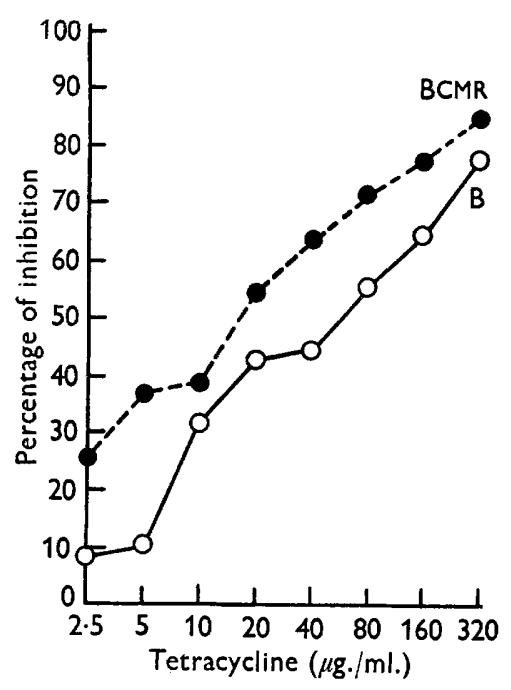

Fig. 3

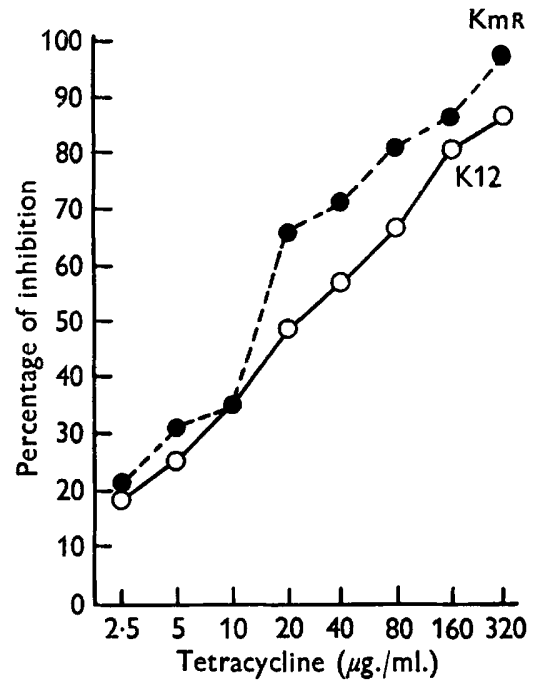

Fig. 4

Fig. 3. Effect of tetracycline on amino acid incorporation by cell-free systems of Escherichia coli B and strain B CMR. Conditions are similar to Fig. 1. Average data of from two to four experiments are shown.

Fig. 4. Effect of tetracycline on amino acid incorporation by cell-free systems of Escherichia coli strains $\mathrm{K}$ and $\mathrm{K} \mathrm{mR}$. Conditions are similar to Fig. 1. Average data of from two to four experiments are shown.

\section{Inhibition of amino acid incorporation by other compounds}

As mentioned above, strain B CMR was also cross-resistant to penicillin, erythromycin, and strain $\mathrm{K} \mathrm{mR}$ to streptomycin. Since it has been observed that erythromycin (Brock \& Brock, 1959) and streptomycin (Eaton \& Caffrey, 1961; Erdös \& Ullmann, 1959; Hahn et al. 1962) have inhibitory effects on protein synthesis, the effects of these compounds on the cell-free system of Escherichia coli B and strain к 12 were examined.

Streptomycin (100 $\mu \mathrm{g} . / \mathrm{ml}$.) exerted diverse effects. With amino acid incorporation by cell-free preparations of relatively low activity, streptomycin exhibited no inhibitory effect and occasionally even an acceleration was observed, especially at higher concentrations (500 $\mu \mathrm{g} . / \mathrm{ml}$. or more). However, amino acid incorporation by preparations with higher activity obtained by the modified method used in later experiments was inhibited by streptomycin to a variable extent. These complicated effects produced by streptomycin are now under investigation in view of the findings 
on the effect of streptomycin on the synthesis of polyphenylalanine directed by polyuridylic acid in a cell-free system (Speyer, Lengyel \& Basilio, 1962; Flaks, Cox \& White, 1962).

Erythromycin inhibited the amino acid incorporation up to $30 \%$ at concentrations of $100-1000 \mu \mathrm{g} . / \mathrm{ml}$. Penicillin (40 $\mu \mathrm{g} . / \mathrm{ml}$.) had no effect on amino acid incorporation, suggesting that this process is not related to the synthesis of cell-wall substance, which is sensitive to inhibition by penicillin (Park, 1958; Mandelstam \& Rogers, 1959).

Table 2. Inhibition by tetracycline of amino acid incorporation by cell-free preparations of various in vitro-developed tetracycline-resistant strains of Escherichia coli $\mathrm{K} 12$

\begin{tabular}{|c|c|c|c|c|c|c|c|}
\hline & \multicolumn{7}{|c|}{ Strain } \\
\hline & \multicolumn{2}{|c|}{ TCR 5 A } & \multicolumn{2}{|c|}{ TCR 5-900 } & \multicolumn{2}{|c|}{ TCR $3 \mathrm{C}$} & $\mathrm{k} 12$ wild \\
\hline & \multicolumn{6}{|c|}{ Degree of resistance (tetracycline $\mu \mathrm{g} . / \mathrm{ml}$.)* } & \\
\hline & \multicolumn{2}{|c|}{$>100$} & \multicolumn{2}{|c|}{ About 120} & \multicolumn{2}{|c|}{ About 50} & $3 \cdot 6$ \\
\hline $\begin{array}{c}\text { Tetra- } \\
\text { cycline } \\
\text { added } \\
(\mu \mathrm{g} . / \mathrm{ml} .)\end{array}$ & $\begin{array}{c}\text { counts/ } \\
\text { min. } \\
\text { incor- } \\
\text { porated } \dagger\end{array}$ & $\begin{array}{l}\text { Inhibi- } \\
\text { tion } \\
\% \%\end{array}$ & $\begin{array}{c}\text { counts/ } \\
\text { min. } \\
\text { incor- } \\
\text { porated }\end{array}$ & $\begin{array}{c}\text { Inhibi- } \\
\text { tion } \\
\%\end{array}$ & $\begin{array}{c}\text { counts/ } \\
\text { min. } \\
\text { incor- } \\
\text { porated }\end{array}$ & $\begin{array}{l}\text { Inhibi- } \\
\text { tion } \\
\%\end{array}$ & $\begin{array}{l}\text { Average } \\
\text { value of } \\
\% \text { of in- } \\
\text { hibition* }\end{array}$ \\
\hline 0 & 1588 & $\mathbf{0}$ & 1176 & 0 & 2024 & 0 & 0 \\
\hline 10 & 1216 & 22 & 952 & 19 & 1732 & 14 & $32(16-45)$ \\
\hline 20 & 1144 & 28 & 842 & 28 & 1528 & 25 & $38(19-47)$ \\
\hline 40 & 1004 & 37 & 648 & 45 & 1400 & 31 & $51(45-67)$ \\
\hline 80 & 704 & 56 & 536 & $\mathbf{5 4}$ & 1284 & 36 & $62(52-80)$ \\
\hline 160 & 412 & 74 & 264 & 78 & 888 & 56 & $77(74-84)$ \\
\hline 320 & 244 & 85 & 116 & 90 & 448 & 78 & $81(68-90)$ \\
\hline
\end{tabular}

Each tube contained equiv. 2-3 mg. protein of dialysed 3s fraction in a total volume of $0 \cdot 3$ $0.5 \mathrm{ml}$. Incubation: $37^{\circ}$ for $45 \mathrm{~min}$. Other conditions are as described in the text. Each experiment made in duplicate.

* The figures indicate the concentration ( $\mu \mathrm{g} . / \mathrm{ml}$.) of tetracycline required for $50 \%$ growth inhibition; tests were made directly on the organisms used for preparation of the cell-free system.

$\dagger$ Total counts measured on samples containing equiv. 1.5-2 mg. protein; the value for the 0 time control, about 100 counts/min., was subtracted. Not corrected for self-absorption.

$\$$ Average value of four to six experiments. The range of variation is shown in parentheses.

\section{DISCUSSION}

It is well established that chloramphenicol specifically inhibits protein synthesis in bacteria (Gale \& Folkes, 1953; Wisseman, Smadel, Hahn \& Hopps, 1954). The amino acid incorporation system of Escherichia coli used in the present work can be considered to approximate to the process of protein synthesis in many respects, and is sensitive to inhibition by chloramphenicol at a concentration slightly higher than that required for growth inhibition. Thus the cell-free amino acid incorporation system may well be regarded as the site of action of chloramphenicol on bacteria. The data presented above indicate that the resistant strains investigated lost their chloramphenicol resistance when they were disrupted to a cell-free preparation. Thus it can be concluded that the primary cause of chloramphenicol resistance in these strains is not alteration(s) in the process of protein synthesis, but is some change(s) in the process by which the compound reaches its site of action, i.e. some change(s) in permeability. 
Since tetracycline acts as a chelating agent, and consequently may exert action on several cellular activities (see review by Weinberg, 1957), its mode of action is not so well defined as is that of chloramphenicol. However, evidence has been given that, at the growth inhibitory concentration, tetracycline inhibits bacterial protein synthesis preferentially (Gale \& Folkes, 1953) as chloramphenicol does. Therefore, it seems likely that the inhibitory effect of tetracycline on the amino acid incorporation system reflects the inhibitory effects of tetracycline on bacterial growth. Although the concentration of tetracycline required for inhibition of the cell-free system is considerably higher than that required for growth inhibition, this may partly be explained by the presence of a rather high concentration of $\mathbf{M g}^{2+}$ (see Results).

If it be assumed that the inhibition by tetracycline of cell-free amino acid incorporation represents its antibacterial effect, tetracycline resistance in strains $\mathrm{B}$ CMR, $\mathrm{K} \mathrm{MR}$ and $\mathrm{K}$ TCR should also be due to changes in permeability as in chloramphenicol resistance. A certain degree of cross-resistance between chloramphenicol, tetracycline and other compounds in in vitro-developed chloramphenicol- and tetracycline-resistant strains of Escherichia coli has been observed (Szybalsky \& Bryson, 1952; Cavalli, 1952); changes in permeability for these compounds would be a plausible explanation for such cross-resistance.

Independently of our preliminary work (Okamoto \& Mizuno, 1962), Akiba \& Yokota (1962) made similar experiments and reached the same conclusion as we did except for the case of the in vitro-developed tetracycline-resistant strain. They reported that the cell-free system of the latter strain was resistant to tetracycline and that this resistance resided in the ribosomal fraction (Yokota \& Akiba, 1962). As described above, all the tetracycline-resistant strains that we isolated, through multiple steps from Escherichia coli $\mathrm{K} 12$ strain cs 101, gave tetracyclinesensitive cell-free systems. These findings do not, of course, exclude the possibility that tetracycline-resistant mutants equipped with tetracycline-resistant proteinsynthesis machinery may occur. We can only say that, in the most easily obtainable tetracycline-resistant strains of $E$. coli $\mathrm{K} 12$, their cell-free systems are not resistant to tetracycline. Although only one in vitro-developed chloramphenicol-resistant strain was investigated, this strain was so resistant (about one thousand times as resistant as the wild strain) that it may be assumed that many of its loci responsible for chloramphenicol resistance have mutated, so that the above considerations can also be applied to chloramphenicol resistance.

The contradiction of our conclusion with that of Ramsey (1958) may be explained by the staphylococcus he used possessing a different mechanism of chloramphenicol resistance from that of Escherichia coli, or by the possibility that the disrupted cell system used by Ramsay still retained some sort of permeability barrier.

Our results do not exclude the possible role of a chloramphenicol-inactivating enzyme (Merkel \& Steers, 1953; Miyamura, 1961) in the chloramphenicol resistance of Escherichia coli, since they only showed that cell-free protein synthesis of resistant organisms was not resistant, and that resistance was probably due to changes other than at the immediate site of protein synthesis. However, the enzymic degradation of chloramphenicol is not sufficiently rapid to decrease the concentration of chloramphenicol in the medium, and our experiments indicate that such an enzyme is not operating in the cell-free system. Hence, if a chloramphenicol- 
inactivating enzyme plays some role in chloramphenicol resistance in $\boldsymbol{E}$. coli, its mode of action might be to decrease intracellular concentration of chloramphenicol by acting on the compound at its entrance into the cell, and this might be one type of change in the permeability barrier. Spheroplasts of chloramphenicol-resistant E. coli remain resistant to chloramphenicol (Hirokawa, Abe \& Mizuno, 1959). The most probable alteration of permeability, if any, is therefore within the spheroplast.

Resistant strains of Escherichia coli derived in vitro and by transferred resistance are somewhat more sensitive than their wild types to polymyxin $\mathrm{B}$, a surface active antibiotic which combines with some surface structure of Gram-negative bacilli. However, attempts to reverse the resistance by combined action of chloramphenicol and polymyxin $\mathbf{B}$ were unsuccessful.

This work was aided partly by a grant to Dr J. Tomizawa from the Jane Coffin Childs Memorial Fund for Medical Research. We wish to thank Drs J. Tomizawa and K. Matsubara for their help and advice. We are indebted to Dr M. Takanami for a gift of guanosine triphosphate. Special thanks are due to Mrs K. Okamoto for her able technical assistance.

\section{REFERENCES}

Aкıва, T. \& Yокота, T. (1962). Studies on the mechanism of transfer of drug-resistance in bacteria. 22. Influences of chloramphenicol and tetracycline on the ${ }^{14} \mathrm{C}$-amino acid incorporation by ribosomes isolated from the drug-sensitive strain and the multiple resistant strain of E. coli. Medicine \& Biology (Tokyo), 64, 34. (In Japanese.)

Brock, D. T. \& Brock, M. L. (1959). Similarity of action of chloramphenicol and erythromycin. Biochim. biophys. Acta, 33, 274.

Cavalur, L. L. (1952). Genetic analysis of drug-resistance. Bull. Wld Hlth Org. 6, 185.

Eaton, N. R. \& CAFFrey, R. (1961). Effect of dihydrostreptomycin on Escherichia coli. J. Bact. 81, 918.

Erdös, T. \& Ullman, A. (1959). Effect of streptomycin on the incorporation of amino acids labelled with ${ }^{14} \mathrm{C}$ into ribonucleic acid and protein in a cell-free system of a Mycobacterium. Nature, Lond. 183, 168.

Flaks, J. G., Cox, E. C. \& White, J. R. (1962). Inhibition of polypeptide synthesis by streptomycin. Biochem. biophys. Res. Commun. 7, 385.

Gale, E. F. \& Folkes, J. P. (1953). The assimilation of amino acids by bacteria. 15. Actions of antibiotics on nucleic acid and protein synthesis in Staphylococcus aureus. Biochem. J. 53, 493.

Hahn, F. E., Ciak, J., Wolfe, A. D., Hartman, R. E., Allison, J. L. \& Hartman, R. S. (1962). Studies on the mode of action of streptomycin. II. Effects of streptomycin on the synthesis of proteins and nucleic acids and on cellular multiplication in Escherichia coli. Biochim. biophys. Acta, 61, 741.

Hirokawa, H., ABe, M. \& Mizuno, D. (1959). Mechanism of chloramphenicol resistance in Escherichia coli. II. Sensitivity alteration to various drugs of chloramphenicol resistant Escherichia coli converted to protoplast. Jap. J. Med. Sci. 12, 119.

Kuschner, D. J. (1955). The basis of chloramphenicol resistance in Pseudomonas fluorescens. Archs. Biochem. 58, 347.

Mandelstam, J. \& Rogers, H. J. (1959). The incorporation of amino acids into the cellwall mucopeptide of Staphylococci and the effect of antibiotics on the process. Biochem. J. $72,654$.

Matthei, J. H. \& Nirenberg, M. W. (1961). Characteristics and stabilization of DNAasesensitive protein synthesis in $\boldsymbol{E}$. coli extracts. Proc. nat. Acad. Sci., Wash. 47, 1580.

Merkel, J. R. \& Steers, E. (1953). Relationship between 'chloramphenicol reductase activity' and chloramphenicol resistance in Escherichia coli. J. Bact. 66, 389. 
Miyamura, S. (1961). Chloramphenicolase in dysentery bacilli, with special reference to chloramphenicol resistance. Jap. J. Bact. 16, 115. (In Japanese.)

Oкамото, S. \& Mizuno, D. (1962). Inhibition by chloramphenicol of protein synthesis in the cell-free system of a chloramphenicol-resistant strain of Escherichia coli. Nature, Lond. 195, 1022.

PARK, J. T. (1958). Inhibition of cell-wall synthesis in Staphylococcus aureus by chemicals which cause accumulation of wall precursors. Biochem. J. 70, 2 P.

Ramsey, H. H. (1958). Protein synthesis as a basis for chloramphenicol-resistance in Staphylococcus aureus. Nature, Lond. 182, 602.

SkaAR, P. D. \& Garen, A. (1956). The orientation and extent of gene transfer in Escherichia coli. Proc. nat. Acad. Sci., Wash. 42, 619.

Speyer, J. F., Lengyel, P. \& Basilio, C. (1962). Ribosomal localization of streptomycin sensitivity. Proc. nat. Acad. Sci., Wash. 48, 684.

Szybalsky, W. \& Bryson, V. (1952). Genetic studies on microbial cross resistance to toxic agents. J. Bact. 64, 489.

Treffers, H. P. (1956). The linear relationship of dosage response curves in microbialantibiotic assays. J. Bact. 72, 108.

Watanabe, 'T. (1963). Infective heredity of multiple drug resistance in bacteria. Bact. Rev. 27, 87.

Weinberg, E. D. (1957). The mutual effects of antimicrobial compounds and metallic cations. Bact. Rev. 21, 46.

Wisseman, C. L., Smadel, J. E., Hahn, E. F. \& Hopps, H. E. (1954). Mode of action of chloramphenicol. I. Action of chloramphenicol on assimilation of ammonia and on synthesis of proteins and nucleic acids in Escherichia coli. J. Bact. 67, 662.

Yокота, T. \& Aкıва, T. (1962). Studies on the mechanism of transfer of drug-resistance in bacteria. 23. Mechanism of antibacterial action of tetracycline and the tetracycline resistance in the artificial tetracycline resistant strain of $E$. coli. Medicine $\&$ Biology (Tokyo), 64, 39. (In Japanese.) 